\title{
INFLUENCE OF THE TIDAL AND RAINFALL CYCLES ON THE POPULATION STRUCTURE AND DENSITY OF Mesacanthion hirsutum GERLACH (NEMATODA, THORACOSTOMOPSIDAE) ON A TROPICAL SANDY BEACH (TAMANDARÉ BAY, PERNAMBUCO, BRAZIL)
}

\author{
Virag Venekey*, Verônica Gomes da Fonsêca-Genevois and Paulo Jorge Parreira dos Santos
}

\author{
Universidade Federal do Pará \\ Instituto de Ciências Biológicas \\ (Av. Augusto Corrêa, 01. 66075-110 Belém, PA, Brasil)
}

*Corresponding author: venekey@ufpa.br

\section{A B S T R A C T}

\begin{abstract}
The population structure (males, females and juveniles) and density of Mesacanthion hirsutum Gerlach were studied during the tides (low, flood, high and ebb) of two consecutive tidal cycles in four different months of the year (May, July, September and November). Mesacanthion hirsutum density variations showed association with the rainfall cycle, with lower densities during July and September and significantly higher values in May and November. The population structure was constituted mostly by juveniles indicating a continuous reproduction during all the studied period. There were no significant differences between light and dark periods of the day, however, the higher densities detected during the high and ebb tidal stages demonstrate that this species could be dispersing through the water column and/or migrating within the sediment.
\end{abstract}

\section{R ESUMO}

A estrutura populacional (machos, fêmeas e juvenis) e densidade de Mesacanthion hirsutum Gerlach foram estudadas durante as marés (baixa, enchente, alta e vazante) de dois ciclos de maré consecutivos, em quatro meses diferentes do ano (Maio, Julho, Setembro e Novembro). As variações de densidade de Mesacanthion hirsutum mostraram associação com o ciclo de chuvas, com densidades mais baixas durante Julho e Setembro e significativamente maiores em Maio e Novembro. A estrutura populacional constituiu-se em sua maior parte por juvenis indicando uma reprodução continua durante todo o período de estudo. Não foram encontradas diferenças significativas entre os períodos claros e escuros do dia, contudo maiores densidades foram detectadas durante as marés altas e vazantes demonstrando que a espécie pode estar se dispersando através da coluna d'água e/ou migrando dentro do sedimento.

Descriptors: Marine nematodes, Meiobenthos, Intertidal environment, Seasonal variations, Brazil Descritores: Nematode marinhos, Meiobentos, Ambiente entremarés, Variações sazonais, Brasil.

\section{INTRODUCTION}

The effect of tides on nematodes has been studied and linked to a variety of both biotic and abiotic environmental factors since the middle of the last century (e.g., RENAUD-DEBYSER; SALVAT, 1963; BOADEN; PLATT, 1971) and also more recently (NICHOLAS, 2001; STEYAERT et al., 2001). These studies were mainly concentrated in temperate regions and most of them considered the total nematode community. One of the most direct reactions to tides in intertidal regions is the dispersal of organisms which might be using different substrates, such as leaves, seaweeds, adhesion to transported sediment (GERLACH, 1977), or the water column (BELL; SHERMAN, 1980; HAGERMAN;
RIEGER, 1981; SIBERT, 1981) or, otherwise, within the sediment itself (PALMER; GUST, 1985).

On the Brazilian coast the investigations into marine nematodes have consisted mainly of taxonomical lists or descriptions (i.e. GERLACH, 1954, 1956a, 1956b, 1957a, 1957b; ESTEVES, 2004; VENEKEY et al., 2005; CASTRO et al., 2006; FONSECA-GENEVOIS et al. 2009) which are certainly necessary and constitute essential first steps to the knowledge of this group on such an extensive coastline. Ecological studies on nematodes at low taxonomical level have just been begun with works such as those of NETTO and GALLUCCI (2003), FONSECA-GENEVOIS et al. (2004), DA ROCHA et al. (2006) and FONSECA-GENEVOIS et al. (2006). Also recently, were published the first studies concerning the population structure of Oncholaimus 
cobbi Kreis, Comesoma arenae Gerlach and Daptonema oxycerca DE MAN by ESTEVES et al. (2003), ESTEVES et al. (2004) and MARIA et al. (2008), respectively.

Mesacanthion hirsutum was described as a new species by Gerlach in (1953) for the Mediterranean Sea, later being found in the Red Sea (GERLACH, 1964; GERLACH, 1967) and the Exe estuary (WARWICK, 1971). Even though this species was discovered more than 50 years ago, nothing is yet known about its population structure. The objectives of the present study were to register the first record of this species on the Brazilian coast and to describe its population structure (males, females and juveniles) and density variations, considering also the influence of the tidal cycle during four different months of the year.

\section{Material and Methods}

The sampling station $\left(08^{\circ} 45^{\prime} 58^{\prime}\right.$ 'S, $35^{\circ} 05^{\prime} 96^{\prime \prime} \mathrm{W}$ ) is located on Tamandaré Bay, about 110 $\mathrm{km}$ south of Recife, Pernambuco, Brazil (Fig. 1). This sandy beach is characterized by quartz sediments varying from fine to medium grain size and the adjacent subtidal area presents coral reef formations lying parallel to the coast (MAIDA; FERREIRA, 1997). According to MCLACHLAN'S (1980) criteria the study area might be classified as a sheltered beach. The tidal amplitude in the area is of about $2.5 \mathrm{~m}$ and the cycle is semidiurnal. The climate is hot and humid, of type Aws, according to the Köppen system. The region, in accordance with the last 50-year average, presents two seasons: a dry season extending from September to February and a rainy season from March to August, with half of the annual rainfall occurring between May and July (SEMA - Science, Technology and Environment Department of Pernambuco State). The daylight period in the area is of around 12-13 hours/day.

The samples were always collected in the upper intertidal zone, at hourly intervals, for $24 \mathrm{~h}$, in four different months of 1991: May, July, September and November. At each sampling six meiofauna replicate cores were collected using a PVC tube (2.5 $\mathrm{cm}$ of inner diameter and $10 \mathrm{~cm}$ deep) and fixed immediately in $4 \%$ formaldehyde solution. In the laboratory, the samples were treated using the routine methods for meiofauna (humid sieving and manual centrifugation) suggested by ELMGREN (1973) and the nematodes sorted using Dollfus plates and a stereoscopic microscope. The individuals of $M$. hirsutum were removed manually using a needle, and permanent slides were made as described by COBB (1917) and DE GRISSE (1969). The animals were identified as males, females and juveniles. The mean density for each tide (low, flood, high and ebb) was calculated using the density values obtained during each tide peak and at preceding and subsequent times.

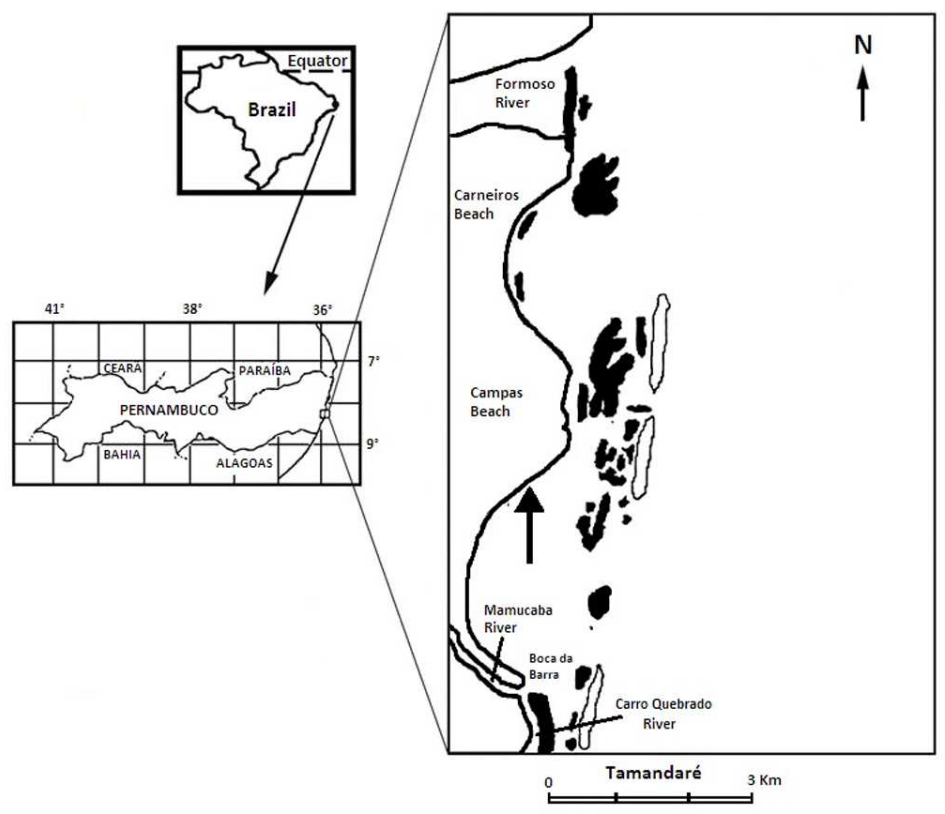

Fig. 1. Map of the sampling site. 
Differences in the population densities between months, tides and light/dark periods of the day were tested by multifactorial analysis of variance (ANOVA) using STATISTICA 5.5 on the data transformed to $\ln (x+1)$. Before the ANOVA the homogeneity of variances was verified using Sen \& Puri's nonparametric test. Post-hoc comparisons were undertaken using the Tukey HSD-test.

The male/female ratio was calculated for each month and tide in order to test the deviations from an expected chi-square distribution.

\section{Results}

The meiofauna in Tamandaré was composed by 10 groups (Turbellaria, Gastrotricha, Tardigrada, Nematoda, Polychaeta, Oligochaeta, Bivalvia, Copepoda Harpacticoida, Ostracoda and Acari) from which Nematoda represented $45 \%$ of the total density considering all the samples together (FonsecaGenevois et al., unpublished data). The nematode community, present in all the months sampled, consisted of 48 genera, $5.2 \%$ of the individuals of
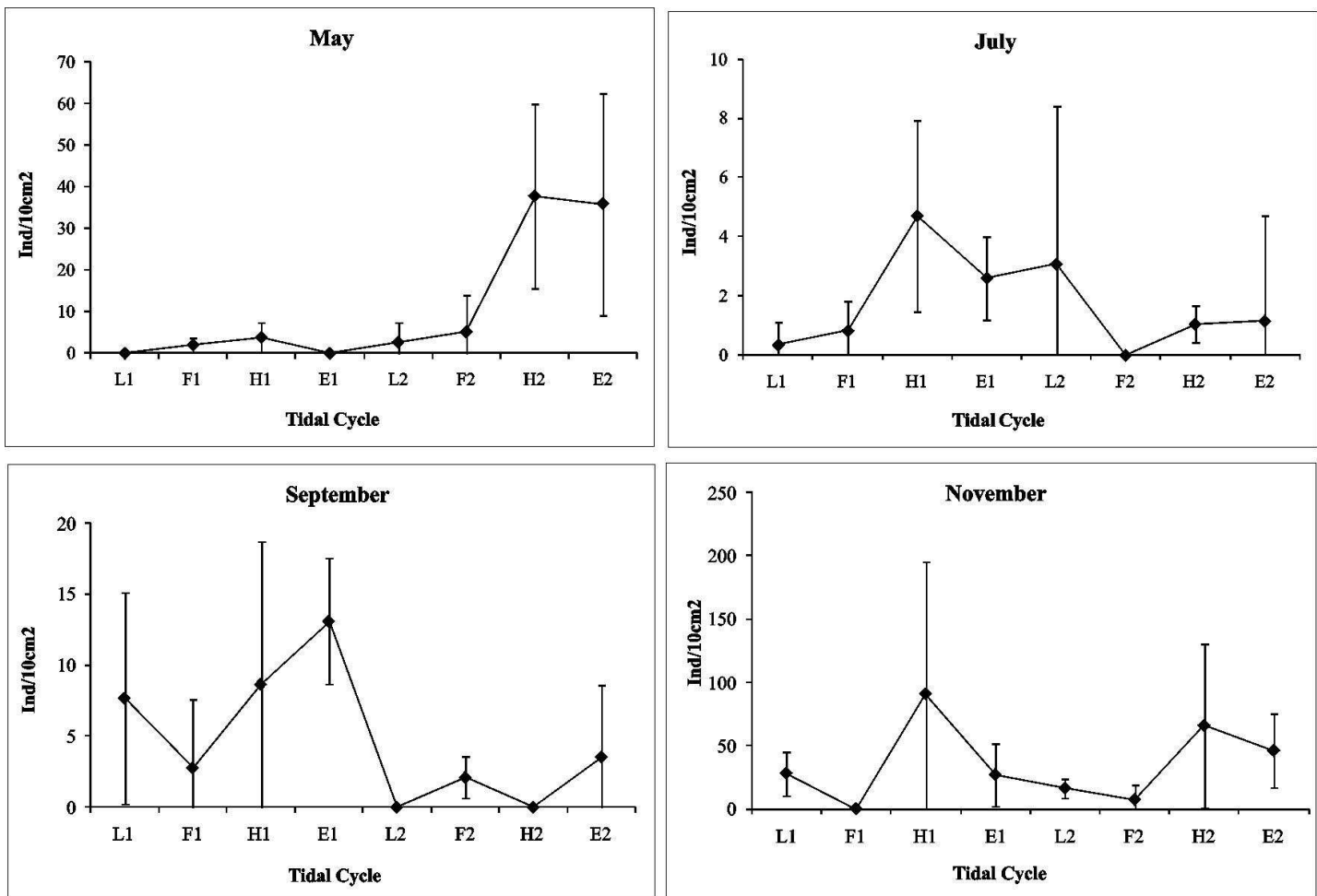

Fig. 2. Total density (ind $\left./ 10 \mathrm{~cm}^{2}\right)$ of Mesacanthion hirsutum during two consecutive tidal cycles (1 and 2) in four different months $(\mathrm{L}=$ low tide; $\mathrm{F}=$ flood tide; $\mathrm{H}=$ high tide; $\mathrm{E}=\mathrm{Ebb}$ tide $)$.

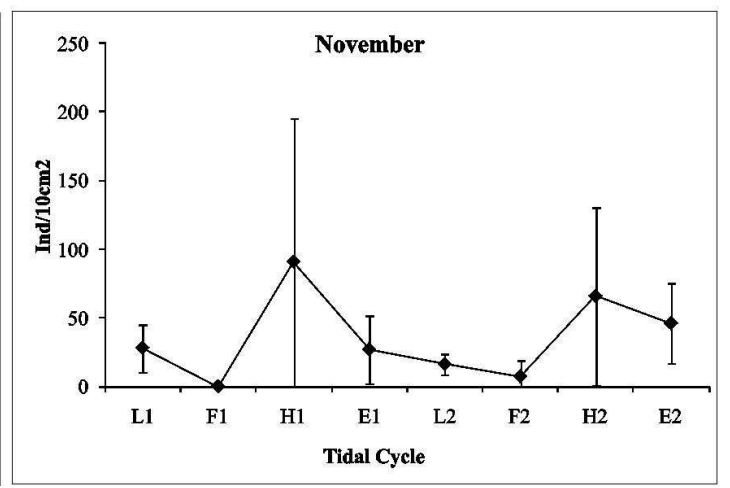

which were of Mesacanthion. In Tamandaré this genus was monospecific, the single species being identified as Mesacanthion hirsutum Gerlach.

The density of $M$. hirsutum did not vary significantly as between the light and dark periods of the day $(\mathrm{p}=0.78)$ but did vary significantly among the four months sampled $(\mathrm{p}<0.01)$ with significantly higher densities in November than in May, July or September (Fig. 2). Statistical differences were also found when densities were compared as between tides $(\mathrm{p}<0.01)$. Although differences can be found in relation to the densities, absences were observed throughout the study period regardless of the month or tide.

The population of $M$. hirsutum was composed mainly of juvenile animals that were dominant during July, September and November. The females, exclusively non-ovigerous, were dominant in May when males were not observed (Table 1). The male/female ratios (Table 01) varied significantly between months $\left(\chi^{2}=81.491 ; \mathrm{p}<0.05\right)$ but did not between tides $\left(\chi^{2}=0.791 ; \mathrm{p}>0.05\right)$. 
Table 1. Mean densities (ind $/ 10 \mathrm{~cm}^{2}$ ) of males, females and juveniles of Mesacanthion hirsutum during two consecutive tidal cycles ( 1 and 2$)$ during four different months $(\mathrm{L}=$ low tide; $\mathrm{F}=$ flood tide; $\mathrm{H}=$ high tide; $\mathrm{E}=\mathrm{ebb}$ tide).

\begin{tabular}{|c|c|c|c|c|c|c|c|c|}
\hline & L1 & F1 & H1 & E1 & L2 & F2 & H2 & E2 \\
\hline \multicolumn{9}{|l|}{ May } \\
\hline Males & 0 & 0 & 0 & 0 & 2.68 & 5.12 & 21.75 & 30.15 \\
\hline Females & 0 & 2.00 & 2.97 & 0 & 0 & 0 & 15.96 & 5.7 \\
\hline Juveniles & 0 & 0 & 0.80 & 0 & 2.68 & 5.12 & 37.71 & 35.85 \\
\hline \multicolumn{9}{|l|}{ July } \\
\hline Males & 0 & 0.32 & 0.96 & 0.61 & 1.23 & 0 & 0.18 & 0.35 \\
\hline Females & 0 & 0.51 & 3.27 & 1.99 & 0.61 & 0 & 0.87 & 0.81 \\
\hline Juveniles & 0.35 & 0.83 & 4.70 & 2.60 & 3.07 & 0 & 1.05 & 1.16 \\
\hline \multicolumn{9}{|c|}{ September } \\
\hline Males & 0 & 0.20 & 0 & 0 & 0 & 0 & 0 & 2.35 \\
\hline Females & 0 & 2.58 & 8.65 & 10.16 & 0 & 2.09 & 0 & 1.17 \\
\hline Juveniles & 7.66 & 2.78 & 8.65 & 12.09 & 0 & 2.09 & 0 & 3.52 \\
\hline \multicolumn{9}{|l|}{ November } \\
\hline Males & 1.81 & 0 & 19.77 & 4.49 & 1.85 & 0.43 & 1.85 & 6.4 \\
\hline Females & 2.19 & 0 & 32.86 & 10.96 & 4.73 & 1.73 & 10.01 & 6.4 \\
\hline Juveniles & 24.13 & 0 & 38.29 & 11.67 & 9.76 & 5.13 & 54.16 & 33.18 \\
\hline
\end{tabular}

\section{DisCUSSION}

The species Mesacanthion hirsutum seems to have a preference for the dry season as the average densities, already low in May $\left(10.89\right.$ ind $\left./ 10 \mathrm{~cm}^{2}\right)$, were even lower in July $\left(1.72 \mathrm{ind} / 10 \mathrm{~cm}^{2}\right)$ and increased in September $\left(4.72 \mathrm{ins} / 10 \mathrm{~cm}^{2}\right)$ and November $\left(35.23 \mathrm{ind} / 10 \mathrm{~cm}^{2}\right)$.

Data on the temporal variation of marine nematodes are scarce in tropical regions but the few existing studies suggest a variation of this group mainly associated with the rainfall cycle, with lower densities occurring during the rainy season (INGOLE; PARULEKAR, 1998; PATTNAIK; RAO, 1990). The data concerning Nematoda in the same study area confirmed this pattern (SOUZA-SANTOS et al, 2003). Although the Nematoda group seems to be associated with the rainfall cycle, ESTEVES et al. (2003), ESTEVES et al. (2004) and MARIA et al. (2008) studying Oncholaimus cobbi, Comesoma arenae and Daptonema oxycerca, respectively, on a tropical tidal flat (Coroa Grande, Rio de Janeiro - Brazil), found that each species behaved differently. Oncholaimus cobbi was more abundant during the warmer and rainy season while $C$. arenae and $D$. oxycerca preferred the colder and dry months. Thus nematode species can have different reactions to the seasonal variations even in tropical areas where climatic changes are not well defined, indicating the importance of studies at low taxonomic level to detect such patterns.

Concerning the tidal cycle, a preference of $M$. hirsutum for the high and ebb tides was observed during this study. This behavior was more obvious in November when the densities were as much as three times higher during these tides than during the flow tides. NICHOLAS and HODDA (1999) found on an Australian temperate sandy beach that when the sea was calm the nematode fauna remained stable for at least 24h (two tidal cycles) during all tide levels and changed only slowly with the passage of time. This fact is certainly not the case with M. hirsutum, whose densities can even quadruplicate from one tide to the next. These great density variations can probably be linked to the dispersion and/or migration of the animals within the sediment or through the water column. Nematode migration to deeper sediment layers during high tides has already been reported by many authors (e.g., MCINTYRE; MURISON, 1973; PLATT, 1977); however, STEYAERT et al. (2001) found in a temperate estuary that some species have the opposite behavior, increasing their densities in the upper layers of the sediment during the submersion periods (high tides).

The population composition of $M$. hirsutum consisting mainly of juveniles (dominant during July, September and November) as well as their continuous presence suggests that this species reproduces continuously. HEIP et al. (1982) have stated that most marine nematode species have many more than one or two generations in the course of a year and in many cases the reproduction is continuous. The fact that all females were non-ovigerous suggests that the ovigerous stage of females is very short or that the preference at this life stage is for deeper sediment layers (below 10cm) which were not sampled in this study. Certainly the complete life cycle could be more easily studied in the laboratory but the predator/omnivorous feeding habits as well as the intertidal habitat of this nematode species make it 
difficult to maintain it in culture (MOENS; VINCX, 1998).

The results obtained by the use of the sampling design of the present study enable us to conclude that M.hirsutum might have continuous reproduction and higher densities in the dry season, the period of the year during which the tidal effect is more pronounced. The differences in the population densities and/or structure of nematode species influenced by either seasonal or tidal variations evidence the pressing need for studies at lower taxonomical level in tropical regions.

\section{ACKNOWLEDGEMENTS}

Virág Venekey wishes to thank CAPES for her postgraduate research scholarship (Brazil) and PJPS the CNPq for his research fellowship.

\section{REFERENCES}

BELL, S. S.; SHERMAN, K. S. Tidal resuspension as a mechanism for meiofauna dispersal. Mar. Ecol. Prog. Ser., v. 3, p. 245-249, 1980.

BOADEN, P. J. S.; PLATT, H. M. Daily migration patterns in an intertidal meiobenthic community. Thalass. Jugoslav., v. 7, p. 1-12, 1971.

CASTRO, F. J. V.; BEZERRA, T. N. C.; SILVA, M. C.da.; FONSECA-GENEVOIS, V. G. da. Spirinia elongata, sp.nov. (Nematoda, Desmodoridae) from Pisa Basin, Pernambuco, Brazil. Zootaxa, n. 1121, p. 53-68, 2006.

COBB, N. A. Notes on Nemas. Contrib. Sci. Nematol., v. 5 , p. 117-128. 1917.

DA ROCHA, C. M. C.; VENEKEY, V.; BEZERRA, T. N. C.; SOUZA, J. R. B. Phytal marine nematode assemblages and their relation with the macrophytes structural complexity in a Brazilian tropical rocky beach. Hydrobiologia., n. 553, p. 219-230, 2006.

DE GRISSE, A. T. Redescription ou modification de quelques techniques utilisés dans 1' étude dês nématodes phytoparasitaires. Mededel. Rijks. Landbouw. Gent., v. 34, p. 351-369, 1969.

ELMGREN, R. Methods of sampling sublittoral soft bottom meiofauna. Oikos n. 15, p. 112-120, 1973.

ESTEVES, A. M. Free-living marine nematodes from Coroa Grande tidalflat (Sepetiba Bay, Rio de Janeiro, Brazil). Biociências, v. 12, n. 2, p. 185-186, 2004.

ESTEVES, A. M.; MARIA, T. F.; WANDENESS, A. P. Population structure of Oncholaimus cobbi (Kreis, 1932) (Nematoda: Oncholaimidae) in a tropical tidalflat. J. mar. biol. Ass. U. K., v. 3, p. 903-904, 2003.

ESTEVES, A. M.; MARIA, T. F.; WANDENESS, A. P. Population structure of Comesoma arenae Gerlach (Nematoda, Comesomatidae) in a Brazilian tropical tidalflat, Rio de Janeiro, Brasil. Rev. Bras. Zool., v. 21, n. 4, p. 775-777, 2004

FONSECA-GENEVOIS, V.; SANTOS, G. A. P.; CASTRO, F. J. V.; BOTELHO, A. P.; ALMEIDA, T. C. M.; COUTINHO, R. Biodiversity of marine nematodes from an atypical tropical coastal area affected by upwelling
(Rio de Janeiro, Brazil). Meiofauna Marina, v. 13, p. 37-44, 2004.

FONSECA-GENEVOIS, V.; SOMERFIELD, P. J.; NEVES, M. H. B.; COUTINHO, R.; MOENS, T. Colonization and early succession on artificial hard substrata by meiofauna. Mar. Biol., n. 148, p. 1039-1050, 2006.

FONSECA-GENEVOIS, V.; SMOL, N.; DECRAEMER, W.; VENEKEY, V. Bernardius lineatus gen. n., sp.n. (Enoplida: Enchelediidae), a remarkable nematode with ornamented cuticle from a Brazilian tropical sandy beach. Nematology, v. 11, n. 2, p. 275-287, 2009.

GERLACH, S. A. Die Nematodenbesiedlung des sandstrandes und des Küstengrundwassers an der italienischen Küste. I. Systematischer Teil. Arch. Zool. Ital., v. 37, p. 517-640, 1953.

GERLACH, S. A. Freilebenden Nematoden aus der Lagoa Rodrigo de Freitas (Rio de Janeiro). Zoolog. Anz., v. 153 , p. 135-143, 1954.

GERLACH, S. A. Brasilianische Merres-Nematoden I. Bolm Inst. oceanogr., v. 5, p. 3-69, 1956a.

GERLACH, S. A. Die Nematodenbesiedlung dês tropischen Brandungsstrandes Von Pernambuco. Kieler Meeresforsch., v. 12, p. 202-218, 1956 b.

GERLACH, S. A. Marine Nematoden aus den Mangrove Gebieten von Cananeia. Brasilianische MeeresNematoden III. Jahrbuch Der Akademie Der Wissenschaften Und Der Literatur In Mainz, v. 5, p. 131176, 1957a.

GERLACH, S. A. Die Nematoden fauna des Sandstrandes nach der Kueste von Mittelbrasilien. Mitt. zool. Mus. Berl., v. 33, p. 411-459, 1957b.

GERLACH, S. A. Freilebende Nematoden aus dem Roten Meer. Kieler. Meeresforsch., v.. 20, p. 18-34, 1964.

GERLACH, S. A. Freilebende Meres-Nematoden Von den Sarso-Inseln (Rotes Meer) 3. Beitrag der Arbeitsgruppe Litoralforschung. Meteor Forschergebn., Reihe d, v.. 2, p. 19-43, 1967.

GERLACH, S. A. Means of meiofaunal dispersal. Mikrofauna Meeresbodens, v. 61, p. 89-103, 1977.

HAGERMAN, G. M.; RIEGER, R. M. Dispersal of benthic meiofauna by wave and current action in Bogue Sound, N.C. USA. Mar. Ecol., v. 2, p. 245-270, 1981

HEIP, C.; VINCX, M.; SMOL, N.; VRANKEN, G. The systematics and ecology of free-living nematodes. Helminthol. Abstr., Ser. B, v. 51, p. 1-31, 1982.

INGOLE, B. S.; PARULEKAR, A. H. Role of salinity in structuring the intertidal meiofauna of a tropical estuarine beach: Field evidence. Ind. J. mar. Sci., v. 27, p. 356-361, 1998.

MARIA, T. F.; SILVA, N. R.; WANDENESS, A. P.; ESTEVES, A. M. Spatio-temporal study and population structure of Daptonema oxycerca (Nematoda, Xyalidae) in Coroa Grande, Rio de Janeiro, Brazil. Braz. J. Oceanogr., v. 56, n. 1, p. 41-50, 2008.

MAIDA, M.; FERREIRA, B. P. Coral reefs of Brazil: an overview. INTERNATIONAL CORAL REEF SYMPOSIUM, 8., 1997, USA. Proceedings... v.. I, p. . 263-274, 1997.

MCINTYRE, A. D.; MURISON, D. J. The meiofauna of a flatfish nursery ground. J. mar. biol. Assoc. U. K., v. 53, p. 93-118, 1973.

MCLACHLAN, A. The definition of sandy beaches in relation to exposure: a simple rating system. S. afr. J. Sci., v.76, p.137-138, 1980. 
MOENS, T.; VINCX, M. On the cultivation of free-living marine and estuarine nematodes. Helgolander Meeresunters., v. 52, p. 115-139, 1998.

NETTO, S. A.; GALLUCCI, F. Meiofauna and macrofauna communities in a mangrove from the Island of Santa Catarina, South Brazil. Hydrobiologia, n. 505, p. 159170, 2003.

NICHOLAS, W. L. Seasonal variations in nematode assemblages on an Australian temperate ocean beach; the effect of heavy seas and unusually high tides. Hydrobiologia, n. 464, p. 17-26, 2001.

NICHOLAS, W. L.; HODDA, M. The free-living nematodes of a temperate, high energy, sandy beach: faunal composition and variation over space and time. Hydrobiologia, n. 394, p. 113-127, 1999.

PALMER, M. A.; GUST, G. Dispersal of meiofauna in a turbulent tidal creek. J. mar. Res., v. 43, p. 179-210, 1985.

PATTNAIK, A.; RAO, M. V. L. Composition and distribution of interstitial meiofauna of the sandy beach at Golpapur, South Orissa Coast. Ind. J. mar. Sci.., n. 19, p. 165-170, 1990.

PLATT, H. M. Ecology of free-living nematodes from an intertidal sandflat in Strangford lough, Northern Ireland. Estuar. coast. Shelf Sci., v. 5, p. 685-693, 1977.

RENAUD-DEBYSER, J.; SALVAT, B. Eléments de prosperité des biotopes des sédiments meubles intertidaux et écologie de leurs populations en microfaune et macrofaune. Vie Milieu, v. 14, p. 463 550,1963
SIBERT, J. R. Intertidal hyperbenthic population in the Nanaimo Estuary. Mar. Biol., v. 64, p.259-265, 1981.

SOUZA-SANTOS, L. P.; RIBEIRO, V. S. S.; SANTOS, P. J.

P.; FONSECA-GENEVOIS, V. Seasonality of intertidal meiofauna on a tropical sandy beach in Tamandaré Bay (Northeast Brazil). J. coast. Res., v. 35, p. 369-377, 2003.

STEYAERT, M.; HERMAN, P. M. J.; MOENS, T.; WIDDOWS, J.; VINCX, M. Tidal migration of nematodes on an estuarine tidal flat (the Molenplaat, Schelde Estuary, SW Netherlands). Mar. Ecol. Prog. Ser., v. 224, p. 299-304, 2001.

VENEKEY, V.; LAGE, L. M.; FONSECA-GENEVOIS, V. Draconema brasiliensis and Draconema fluminensis (Chromadorida, Draconematidae): two new species of free living nematodes from a rocky shore affected by upwelling on the Brazilian coast. Zootaxa, n. 1090, p. 51-64, 2005.

WARWICK, R. M. Nematode associations in the Exe estuary. J. mar. biol. Ass. U.K., v. 51, p. 439-454, 1971.

(Manuscript received 10 October 2010; revised 18 May 2011; accepted 25 July 2011) 